\author{
ks. Arkadiusz Olczyk \\ Częstochowa
}

\title{
„Nowe” problemy wychowawcze w dobie „nowych” mediów
}

W klasycznej pedagogice, sięgającej swymi korzeniami czasów starożytnej Grecji, o wychowaniu decydowało uformowanie poszczególnych cnót stanowiących podstawę paidei ${ }^{1}$. Jej celem było ukształtowanie człowieka pięknego moralnie oraz mądrego. Poprzez wychowanie w oparciu o najszlachetniejsze ideały i najdoskonalsze wzorce etyczne młody człowiek opanowywał swoją niesforną naturę i popędy, stając się „pięknym moralnie” (kalos kai agatos). Postmodernizm ${ }^{2}$ przyniósł ze sobą wiele zmian kulturowych, także nową koncepcję pedagogiki, dostosowanej do wyzwań nowoczesnego społeczeństwa. Za prawdę obowiązującą uznawany jest aksjomat: „Jestem tym, za kogo się uważam i jakim się ukształtuję". Wychowanie według

${ }^{1}$ Paideia (gr. pais - dziecko) dosłownie oznacza wychowanie, wykształcenie dziecka. Takie rozumienie pojęcia paidei sięga poematów Homera i Hezjoda, dzieł antycznych poetów i tragików greckich, artystów, w szczególności zaś filozofów oraz instytucji społecznych o charakterze wychowawczym - prawa, tradycji, ustroju państwa-miasta (polis), narodzin szkolnictwa. Por. M. Węcowski, Paideia, [w:] Wielka Encyklopedia PWN, red. K. Wojnowski, t. 20, Warszawa 2004, s. 166-167; P. Jaroszyński, Paideia, [w:] Powszechna Encyklopedia Filozofii, red. A. Maryniarczyk i in., t. 7, Lublin 2000, s. 949.

${ }^{2}$ Postmodernizm, inaczej ponowoczesność, określa szereg tendencji we współczesnej kulturze, sztuce, literaturze, filozofii nauki, życiu społeczno-politycznym. Termin ten został użyty po raz pierwszy w 1946 przez A. Toynbee, rozpowszechniony w latach 70. XX wieku. Postmodernizm występuje przeciw obiektywizmowi w nauce, przeciw racjonalizmowi, idei jedności, całości i systemowości, a także przeciw wszelkim całościowym doktrynom filozoficznym. W zamian proponuje heterogeniczność, ambiwalencję, antyfundamentalizm, dekonstrukcję.Za najwybitniejszych przedstawicieli postmodernizmu w literaturze uznawani są: G. García Márquez, C. Fuentes, J. Barth, T. Pynchon, W. Burroughs, E. Doctorow, M. Kundera, U. Eco, D. Barthelme. 
postmodernistów jest kształtowaniem człowieka „,bez właściwości” ${ }^{3}$, bez tożsamości, człowieka „rozbrojonego moralnie”. Człowiek taki nie wierzy w prawdę obiektywną, odrzuca wartości absolutne, uważa się za prawdziwie „wolnego", zadowala się otrzymywaniem dowolnych aksjologicznie informacji, o których sam decyduje, czy są prawdziwe, czy fałszywe. Taki człowiek czuje się, jak ryba... w sieci, w internecie.

\section{Dzieci facebooka $=$ faceboga}

Założony w lutym 2004 roku Facebook staje się największym dyktatorem XXI wieku. Stał się wręcz „bogiem” dla ponad pół miliarda ludzi na świecie, z czego 8 milionów w Polsce ${ }^{4}$. Niektórzy twierdzą, że jeśli cię nie ma na Facebooku, to nie istniejesz. Ze względu na gigantyczną skalę tego fenomenu twórca Facebooka, 27-letni Mark Zuckerberg ${ }^{5}$ został wybrany przez redakcję tygodnika „Time” Człowiekiem Roku 2010. Nowa generacja nie widzi już różnicy między rzeczywistością (realem) a internetem (wirtualem) - to wstrząsający wynik badań prof. Mikołaja J. Piskorskiego z Harvard Business School przeprowadzonych na 300 tys. użytkowników Facebooka ${ }^{6}$. Z pozoru Facebook wygląda niewinnie - przypomina interaktywną gazetkę redagowaną przez grono znajomych, którzy założyli tam swój profil, by się komunikować i dzielić informacjami. Jeden szuka dobrego fryzjera lub krawca, drugi poleca muzyczne hity czy dobry film, trzeci wrzuca zdjęcia z wycieczki lub wakacji. Facebook przypadł do gustu

${ }^{3}$ Człowiek bez właściwości - taki właśnie tytuł nosi psychoanalityczna powieść Roberta Musila, uznawana za jedno z najwybitniejszych dzieł XX-wiecznej prozy awangardowej. Zob.C. Michalski, Powrót człowieka bez właściwości, Warszawa 1996; J. A. Sobkowiak, Człowiek bez właściwości a cnota. W poszukiwaniu duchowego horyzontu, „Teologia i moralność” 2009, t. 6, s. 11-24.

${ }^{4}$ Przed Facebookiem bronią się wciąż Rosja i Chiny, nie ma go też na Saharze i w Amazonii.

${ }^{5}$ Bank Goldman Sachs wycenił Facebooka na 50 mld dolarów, udziały Marka Zuckerberga są warte $15 \mathrm{mld}$. Jest on najmłodszym miliarderem świata.

${ }^{6} \mathrm{~W}$ ciągu 1 minuty na Facebooku:

- są udostępniane 50304 linki;

- wysyłamy 74204 zaproszenia na różne wydarzenia;

- dodajemy 79364 nowe wpisy;

- klikamy w „lubię to” 382861 razy;

- dodajemy 135849 zdjęć;

- wysyłamy 231.605 wiadomości. 
głównie młodym ludziom, którzy nie pamiętają już świata bez internetu. „Dzieci Facebooka” stanowią generację o innej mentalności ${ }^{7}$.

$\mathrm{Z}$ badań prowadzonych m.in. przez University of Southern California wynika, że mózg człowieka, obcujący niemal stale z internetem, zaczyna pracować na innych obrotach. Przede wszystkim nie nadąża z przetwarzaniem informacji (dziennie wchłaniamy ich nawet 34 gigabajty, co odpowiada 100 tys. słów) i przechodzi w tryb awaryjny. Odłączona zostaje kora przedczołowa, czyli ta część mózgu, która jest odpowiedzialna za empatię, altruizm, uczucia wyższe. $W$ efekcie człowiek obojętnieje na to, co nie dotyczy go osobiście. Aby zareagować na widok potrzebującego, sam potrzebuje już nie 2, ale aż 8 sekund. Tyle czasu zajmuje przetworzenie tego, co widzimy, na to, co czujemy. Ci, dla których internet jest stałym towarzyszem i wychowawcą od dzieciństwa, coraz bardziej przypominają ludzi chorych na autyzm. Mają problemy z komunikowaniem uczuć, rozumieniem cudzego punktu widzenia i utrzymywaniem relacji społecznych: unikają kontaktu wzrokowego, słabo radzą sobie z odczytywaniem mowy ciała - uważa prof. Gary Small. Ów psychiatra z University of California w Los Angeles nazywa to młode pokolenie "cyfrowymi tubylcami". Zapamiętują oni mnóstwo informacji, ale nie potrafią ich zinterpretować na własny użytek - kreatywność bardzo się dziś ceni, ale coraz mniej ludzi jest do niej zdolnych.

Facebook stał się dzisiaj okiem Wielkiego Brata. Rozwija się błyskawicznie i pogłębia zmiany społeczne w rewolucyjnym trybie. Wszelkimi sposobami dąży do obnażania prywatności użytkowników. Pani Joanna Niewiadomska pisze, iż od najnowszych propozycji Zuckerberga, na razie testowanych na amerykańskim Facebooku, jeżą się włosy. Chodzi o automatyczne rozpoznawanie osób na fotografiach i lokalizowanie użytkowników. System porównuje twarze na zdjęciach z profilami w bazie i - jeśli znajdzie identyczną - podpisuje pod zdjęciem, kto jest na nim obecny! Autorka zauważa, że o ile człowiek może mieć opory, żeby oznaczyć na zdjęciu np. pijaną czy obnażoną koleżankę, system takich skrupułów mieć nie będzie. A jeśli w ten sposób zaczną być identyfikowani żołnierze, tajni agenci, policjanci? Jakie szanse będą mieć tajne operacje, gdy twarze i nazwiska osób w nie zaangażowanych będą dostępne w internecie po kilku kliknięciach?

\footnotetext{
${ }^{7}$ Por. B. Mezrich, Miliarderzy z przypadku. Początki Facebooka. Opowieść o seksie, pieniądzach, geniuszu i zdradzie, Warszawa 2010, s. 13-14.

${ }^{8}$ Por. J. Nikodemska, Jak nas psuje Facebóg?, „Focus” 2011, nr 2 (185), s. 32.
} 
Albo gdy znana będzie ich lokalizacja, bo to z kolei umożliwia kolejna nowa usługa na Facebooku - geotagowanie, czyli automatyczne określanie współrzędnych geograficznych ${ }^{9}$. Zapewne te nowe „udogodnienia” Facebooka zostaną dostrzeżone przez złodziei.

Na jawności danych korzysta także świat biznesu. Z badań Eurocom Worldwide wynika, że prawie 35 proc. firm ma już stronę na Facebooku (tzw. fanpage). Ten serwis otwiera przed nimi nowe możliwości - sprzedaż opartą na relacjach. Cel osiąga się nie tylko poprzez reklamę, ale zdobywając sympatię fanów i licząc, że wypromują markę wśród znajomych ${ }^{10}$.

Prof. Tomasz Szlendak, socjolog z Uniwersytetu Mikołaja Kopernika w Toruniu, zauważa, iż cała współczesna kultura opiera się na szybkich zderzeniach z innymi osobami, zaś Facebook to zjawisko pogłębia. Dziś kogoś lubisz, jutro go ukrywasz, pojutrze usuwasz ze znajomych. Temu zdepersonalizowanemu prawu zaczynają podlegać też związki. Z badań wynika, że 5 proc. osób rzuciło kogoś, pisząc e-mail, 6 proc. przez Twittera, a 13 proc. zerwało, zmieniając status na Facebooku i nie mówiąc o tym partnerowi. A przecież zmiana statusu - ze „w związku” na „wolny” - oznacza automatyczne upublicznienie czyjejś osobistej sprawy.

Dzisiejsze pokolenie młodzieży internetowej prawie nie odróżnia informacji od kreacji. W rezultacie w ciaggu ostatnich 20 lat poziom narcyzmu wzrósł o 65 proc. $^{11}$, zaś ludzie urodzeni po 1982 roku to najbardziej narcystyczna generacja w historii - ogłosiła po wielu latach badań amerykańska psycholog dr Jean Twenge. Narcyzmowi sprzyja anonimowość w sieci. Np. na Facebooku aż roi się od awatarów - wirtualnych profili o fałszywych

${ }^{9}$ W 2008 roku wybuchła afera, gdy czterech oficerów Służby Kontrwywiadu Wojskowego umieściło na portalu Nasza Klasa zdjęcia z bronią i w mundurach. Ich praca jest tajna, zajmują się ochroną polskich żołnierzy na misjach zagranicznych, a w tym serwisie społecznościowym wystąpili pod własnymi nazwiskami. Paweł G., pozujący na tle mapy Afganistanu, napisał: „To ja w turbanie i narzucie lokalsa”. „Załoga G. na misji. Komu w drogę, temu kopa” - chwalił się Jarosław B. Panowie oczywiście nie przewidzieli, że mogli w ten sposób narazić na śmiertelne niebezpieczeństwo siebie, kolegów i całą misję.

${ }^{10}$ W taki właśnie sposób rozreklamowany został horror Paranormal Activity. Film nakręcony za 15 tys. dol. zarobił 7 mln dol. tylko dzięki wsparciu „fanów” z Facebooka i Twittera.

${ }^{11}$ Badania dr Róży Bazińskiej, psychologa społecznego z Instytutu Psychologii Uniwersytetu Gdańskiego potwierdziły, że osoby narcystyczne mają problemy w relacjach interpersonalnych. Są skoncentrowane na sobie, mało empatyczne, ludzi traktują instrumentalnie, trudno im angażować się w głębsze relacje. Por. R. Bazińska, K. Drat-Ruszczak, Struktura narcyzmu w polskiej adaptacji kwestionariusza NPI Ruskina i Halla, „Czasopismo Psychologiczne” 2000, t. 6, nr 3-4, s. 171-188. 
personaliach, zdjęciach i życiorysach. To wszystko sprawia, że świat wirtualny kształtuje trendy kulturowe, mody, także wzorce wychowawcze. Obecne młode pokolenie jest zapatrzone w siebie i przekonane o własnej niepowtarzalności, oczekuje więc podziwu otoczenia. Wychowujemy pokolenie "niezdolne do realnej samooceny” ${ }^{12}$. Facebook - sprawując „rząd dusz" - dodatkowo pogłębia te tendencje, wrzucając młodzież w sieć wirtualnej władzy, na wzór tej opisanej przez Orwella ${ }^{13}$.

Potencjał Facebooka, Twittera, MySpace'a, YouTube'a i blogów jest ogromny ${ }^{14}$. Łatwość nawiązywania kontaktów oraz anonimowość w sieci nierzadko prowadzą do rozstroju emocjonalnego, deformacji więzi uczuciowej z najbliższymi, a nawet do zaburzeń osobowości i trudności z rozróżnianiem świata wirtualnego od tego, który naprawdę nas otacza. Ten destrukcyjny proces pogłębiają dodatkowo gry komputerowe.

\section{Niewolnicy gier komputerowych}

Na okładkach gier komputerowych widać prawie wyłącznie zdeformowane postaci ludzkie, seryjnych morderców, wyzywająco ubrane kobiety, kosmitów, machiny uzbrojone w oręż, który raczej nigdy nie powstanie, wreszcie potwory, a czasem i demoniczne postaci. Wizyta w sklepie z takimi grami może skłonić do wniosku, że z naszym społeczeństwem stało się coś bardzo złego.

Gry komputerowe są stosunkowo nowym zjawiskiem społeczno-kulturowym - w Polsce pojawily się dopiero pod koniec lat 80. XX wieku - jednak z badań przeprowadzonych na przełomie lat 2000 i 2001 wśród młodzieży w wieku 13-14 lat wynika, że już wówczas 79 proc. badanych przyznawało się do korzystania z gier komputerowych (w tym 92 proc. chłopców i 67 proc. dziewcząt) ${ }^{15}$. Psycholodzy z Uniwersytetu Stanowego

${ }^{12}$ J. M. Twenge, Generation Me, New York 2006, s. 19.

${ }^{13}$ George Orwell w powieści Rok 1984 (pierwsze wydanie w 1949 r.) opisuje świat przyszłości, w którym życie jednostek zostaje podporządkowane wszechpotężnej władzy Wielkiego Brata.

${ }^{14}$ Amerykański prezydent Barack Obama nie ukrywa, że swoją elekcję zawdzięcza w dużym stopniu właśnie Facebookowi i Twitterowi. Por. P. Levinson, Nowe nowe media, przekł. M. Zawadzka, Kraków 2010, s. 10 i 18-19.

${ }^{15}$ Badania wśród uczniów szkół podstawowych i gimnazjów wykazały, że w ciągu tygodnia chłopcy spędzali przed komputerem 13 godzin, a dziewczęta 5,5 godziny. Należy sądzić, że w ciągu dekady, która upłynęła od przeprowadzenia badań, podane wartości procentowe jeszcze wzrosły. 
Iowa po przebadaniu ponad 130 tysięcy osób na całym świecie ustalili, iż „narażenie na przemoc zawartą w grach komputerowych zwiększa prawdopodobieństwo wystąpienia zachowań agresywnych w perspektywie krótko- i długoterminowej"16. Badania wykazały, że u osób, które mają kontakt z brutalnymi grami komputerowymi - niezależnie od płci, wieku oraz kultury, w której są wychowywane - pojawiają się agresywne myśli i zanikają zachowania prospołeczne.

Profesor Mark Griffiths, psycholog z Nottingham Trenty University, zwraca uwagę na to, że gry komputerowe stają się często instruktażem mordowania ${ }^{17}$. Podstawowym kluczem do zrozumienia niszczycielskiego wpływu gier komputerowych jest relatywizm, bardzo często przejawiający się w możliwości bezkarnego wyboru pomiędzy dobrem a złem w scenariuszu gry, przy czym wybory moralnie złe bywają nagradzane (jako chociażby bardziej skuteczne). W szeroko znanej grze Quake II przechodzi się przez etap, w którym ludzie porwani przez „obcych” wpadają do młyna, są zgniatani tłokami, a wciąż żywe osoby zachowują się jakby straciły rozum. W Blood II: The Chosen można zobaczyć zakrwawione nogi wystające z pralki, a utracone w starciach zdrowie odzyskuje się, zbierając serca ofiar. W Quake IV gracz przechodzi amputację kończyn bez znieczulenia, a uratowany przez żołnierzy walczy, używając nowych członków ${ }^{18}$.

Sceny mordowania na rozmaite sposoby i rozczłonkowywania ofiar rozgrywają się w otoczeniu, którego estetyka jest mroczna, a motorami iście piekielnej atmosfery są nie tylko kształty i kolory, ale również i muzyka; ciężka, metalowa lub psychodeliczna. Nastrój mroku, strachu, rozpaczy oswaja człowieka ze złem, piekłem i demonami, równocześnie usiłując go przekonać o porażce Boga odniesionej w stworzeniu. A to już przecież prosta ścieżka do satanizmu. Skoro taki klimat jest obecny w grach

${ }^{16}$ Por. G. Pabijan, Wirtualny przedsionek piekła, „Polonia Christiana” 2010, nr 16, s. 43.

${ }^{17}$ W roku 2004 w Wielkiej Brytanii siedemnastoletni Warren Leblanc skazany został za zamordowanie czternastoletniego Stefana Pakeerah, któremu zadał liczne ciosy nożem i młotkiem. Zdaniem rodziców zamordowanego Leblanc miał obsesję na punkcie gry Manhunt. „Jeśli przyjrzeć się temu, co Warren zrobił Stefanowi i brutalności oraz okrucieństwu gry, widzi się powiązania" - skomentowała matka zabitego. W efekcie wiele sklepów wycofało grę ze sprzedaży. Jednak wydawca gry - firma Rockstar North - wykręcił się wymówką, iż gra przeznaczona była dla osób pełnoletnich. Por. M. Griffiths, Gry i hazard. Uzależnienia dzieci w okresie dorastania, przekł. A. SawickaChrapkowicz, Gdańsk 2004, s. 23.

${ }^{18}$ Por. G. Pabijan, Wirtualny przedsionek..., dz. cyt., s. 44. 
komputerowych, to czyż można się dziwić, że spotykamy w nich również bezpośrednie odniesienia do szatana? Pentagram, trzy szóstki, odwrócone krzyże, kozioł - te przedmioty niekiedy towarzyszą graczowi w trakcie jego „heroicznych" zmagań. Symbolami satanistycznymi bywają niekiedy oznaczone tajne przejścia, schowki z bronią bądź inne „dobra” przeznaczone dla gracza - znaki te nabierają więc dla niego pozytywnej konotacji. Tytuły zresztą mówią same za siebie: Doom, Diablo, Heretic czy Hexen ${ }^{19}$.

Warto również zauważyć, że gry komputerowe niosą ryzyko straty czasu. Pomijając kwestię ilości godzin spędzanych przed komputerem, należy się zastanowić, czemu one właściwie służą? Cóż przychodzi graczowi z zabicia tysięcznego potwora albo ukończenia kolejnej „strzelanki”? Co mu dają tony informacji o zmyślonych światach fantasy czy science-fiction $\mathrm{i}$ ich wewnętrznych problemach? Raczej niewiele.

Długie i częste korzystanie z gier komputerowych może także doprowadzić do uzależnienia, objawiającego się bezsennością, drżączką czy depresją. Bez wątpienia długie siedzenie przed monitorem źle wpływa również na zdrowie fizyczne. W skrajnych przypadkach ryzykuje siężyciem, czasem nawet nie tylko własnym, ale i bliskich ${ }^{20}$.

Opisane powyżej problemy zmuszają do wielkiej ostrożności, zwłaszcza jeśli idzie o dobro dzieci. Jedynym sposobem na sprawdzenie, co tak naprawdę kryje się w wybranym produkcie, jest opinia osoby zaufanej, która ten produkt dobrze zna. Podane na opakowaniu kategorie wiekowe czy zdobiące je grafiki bynajmniej nie stanowią wiarygodnego probierza treści gier. Dlatego warto się poważnie zastanowić, czy nie zrezygnować z zakupu gry na rzecz dobrej książki, płyty z piękną muzyką czy choćby chomika. Nawet jeśli zdarzy mu się ugryźć naszą pociechę, będzie to dla niej lekcja prawdziwego życia, a nie wirtualnej rzeczywistości ${ }^{21}$.

\footnotetext{
${ }^{19}$ Por. tamże, s. 45. W kontekście obecności złego ducha w grach komputerowych do myślenia daje historia szesnastoletniego Chińczyka Hu-Bin, który po jedenastu dniach grania bez przerwy postanowił popełnić samobójstwo, połykając toksyczny pestycyd. Jak stwierdził, zrobił to, aby już nikt nie mógł go uratować. Zwierzył się matce, że nie jest w stanie się kontrolować i że ciągle chce mu się grać, traciłi odzyskiwał przytomność i nie wiedział, czy znajduje się w realnym świecie, czy nie.

${ }^{20}$ Uzależnione od gier sieciowych małżeństwo zagłodziło własne trzymiesięczne dziecko - spędzając czas, który winno mu było poświęcić, na „wychowywaniu” wirtualnej córki w grze PRIUS.

${ }^{21}$ Por. G. Pabijan, Wirtualny przedsionek..., art. cyt., s. 46.
} 


\section{Wirtualna nirwana}

Ekran komputera oszałamia magią kolorów, szybkimi zmianami obrazów i zwrotami akcji. Nie bez znaczenia jest także ciągła pogoń za nowościami, za ciekawostkami, które wprowadzają umysł w rodzaj specyficznego pobudzenia i niepokoju. Dziecko (czy nastolatek) pozostawione w tej sferze bez opieki zostanie wciągnięte w kolorowy wir i porwany do wirtualnego świata, w którym utracimy z nim kontakt ${ }^{22}$. Powstają już specjalne kliniki leczące internetowe uzależnienia ${ }^{23}$.

W jaki sposób rodzice mogą poznać, że z dzieckiem dzieje się coś niedobrego? Według Marka Griffithsa o uzależnieniu świadczy emocjonalne podporządkowanie danemu działaniu (nieustanne myślenie na dany temat); tzw. tolerancja dawkowania (np. stopniowe wydłużenie czasu przebywania w sieci, aby osiągnąć pierwotny stan oszołomienia); negatywne objawy odstawienia (nieprzyjemne uczucia i objawy fizjologiczne w przypadku zaprzestania określonych działań); zewnętrzny konflikt z otoczeniem lub konflikt wewnętrzny, przejawiający się dyskomfortem psychicznym z powodu braku kontroli nad sobą; nawrót do nałogowych zachowań (nawet po latach) oraz niespodziewane zmiany nastroju ${ }^{24}$.

Uzależnienie prowadzi do określonych skutków, czyli pojawiania się skaz na psychice, które klasyczna pedagogia nazywa wadami moralnymi. W skrajnych przypadkach mamy do czynienia z zachowaniami psychopatycznymi. Wiosną 2009 roku w niemiecki miasteczku Winnenden pod Stuttgartem 17-letni uczeń Tim Kretschmer zamordował 15 osób: kolegów, nauczycieli i przypadkowych przechodniów, a następnie popełnił samobójstwo. Jego rodzicom całkiem nieźle się powodziło: mieli dom, porsche, a chłopak dostawał, co chciał. W wieczór przed zamachem „trenował zabijanie” na jednej z gier komputerowych. Na twardym dysku oprócz gier znaleziono kilka

${ }^{22}$ Użycie w tym przypadku słowa „porwanie” nie jest bynajmniej przesadą. Niech o tym zaświadczy przypadek trzynastoletniego chłopca z Genui, chorobliwie uzależnionego od gier wojennych. Przestał on chodzić do szkoły, nie chciał jeść, praktycznie cały swój czas spędzając przed ekranem komputera. Bezradna matka wezwała w końcu na pomoc karabinierów, którzy skonfiskowali konsolę do gier. Por. D. Zalewski, Wychowanie wepoce cyfrowej, „Polonia Christiana” 2010, nr 16, s. 46.

${ }^{23}$ Funkcjonują one już w Stanach Zjednoczonych, Korei Południowej, a ostatnio także w Holandii.

${ }^{24}$ Por. M. Griffiths, Gry i hazard..., dz. cyt., s. 77-78. 
horrorów i zdjęcia pornograficzne. Chłopak ów trwał w „oszołomieniu” wywołanym $\mathrm{m}$. in. przez nierozsądne korzystanie z komputera ${ }^{25}$.

Ten i podobne przypadki uświadamiają, że nowe technologie mają ogromny wpływ na styl życia i poglądy młodego pokolenia. To, co dla ich rodziców było kwestią sciencefiction, dla młodzieży jest codziennością, bez której nie wyobraża sobie życia. Młodzi funkcjonują w świecie internetu, komunikatorów i technologicznych gadżetów. Z jednej strony izolują się od rzeczywistości i zanurzają w wirtualne światy, z drugiej - dzięki komunikatorom - ich więzi rówieśnicze są silniejsze niż dawniej. Komunikatory, takie jak Gadu-Gadu, czy po prostu zwykłe telefony komórkowe sprawiają, że utrzymują oni ze sobą kontakt nie tylko podczas pobytu w szkole, ewentualnie w trakcie krótkich spotkań po lekcjach, ale często do późna w nocy. Niemal non stop rozmawiają ze sobą: plotkują o znajomych, zwołują się na akcje, umawiają itp. Z wielości interakcji rodzi się nie tylko silna więź rówieśnicza (izolująca od rodziców), ale przez tę intensywność mamy zwielokrotnione konflikty i problemy związane z funkcjonowaniem psychiki w wieku dorastania. Młodzi ludzie nie zawsze sobie z nimi radząa ${ }^{26}$.

Znaczenie opinii kolegów i norm grupowych jest w wieku dorastania szczególnie ważne. Ciągłe przebywanie ze sobą (dzięki wspomnianym technologiom) wymaga stałego potwierdzenia lojalności wobec grupy (nie tylko w szkole, ale i w domu). Z tego względu podporządkowanie grupie środowiskowej w wielu przypadkach przyjmuje rozmiary wręcz groteskowe. Rodzice schodzą na drugi plan. Przestają być słuchani, a niekiedy pojawia się w stosunku do nich nuta pogardy. Związane jest to znowu ze współczesną technologizacją życia. Amerykański myśliciel Marc Prensky wyróżnił "cyfrowych tubylców" (czyli młodych urodzonych w latach 90. ubiegłego wieku) oraz „cyfrowych emigrantów” (czyli dorosłych). Pierwsi doskonale funkcjonują w świecie cyfrowych technologii, w których dorastali i które są niejako ich naturalnym środowiskiem. Drudzy zaś muszą dopiero uczyć

\footnotetext{
${ }^{25}$ Por. D. Zalewski, Zbłąkane pokolenie, „Nasz Dziennik” 2010, nr 223, s. 13.

${ }^{26}$ Problem zaczyna się najczęściej już w dzieciństwie, w uzależnieniu od ekranu komputera. Dlatego najlepszym sposobem wychowawczym jest roztropne dawkowanie kontaktów z komputerem. Niestety, wielu rodziców ma z tym spore kłopoty. Niebezpieczną tendencją jest traktowanie go jako swego rodzaju darmowej niańki. Posadzenie dziecka przed ekranem i włączenie gier daje rodzicom „święty spokój”. Mogą się zająć pracami domowymi lub po prostu w spokoju i ciszy odpocząć. Tymczasem pozostawianie dziecka „pod opieką komputera” jest nie tylko przyczyną rozwoju nowych wad, ale także następstwem wad już istniejących. Por. D. Zalewski, Wychowanie..., dz. cyt., s. 47.
} 
się „cyfrowego języka”. Taka sytuacja wzmaga w młodych poczucie wyższości i przewagi intelektualnej nad dorosłymi.

Nie ulega wątpliwości, że „nowe media” (pomimo swoich zalet) bywają dosyć wysublimowanymi narzędziami pokus, przez co stanowią istotną przeszkodę na drodze do ukształtowania się prawego charakteru. I nie chodzi tu jedynie o treści, jakie ze sobą niosą, ale również o specyficznie zniewalającą formę "oszałamiającego" przekazu. Dlatego jednym z podstawowych postulatów wychowawczych jest przygotowanie dziecka oraz młodego człowieka do korzystania z technologii informatycznych. Nie chodzi tu tylko o instruktaż na temat ewentualnych zagrożeń, ale o uformowanie podstawowych cnót moralnych (powściągliwość, umiar) ${ }^{27} \mathrm{~W}$ takim stopniu, aby mogli oni poradzić sobie z pokusami, które napotkają, siedząc przed ekranem komputera.

\section{Zakończenie}

Jak widać, „oszołomienie” internetem z jednej strony wymaga specjalnego podejścia, bo mamy do czynienia z pojawieniem się nowej przestrzeni dla wychowania, z drugiej zaś - skuteczność podejmowanych działań wciąż opiera się na sztuce kształtowania u dzieci i młodzieży cnót moralnych. Tymczasem nieraz słyszy się głosy, iż nowa sytuacja wymaga „nowoczesnego podejścia" pedagogicznego. Pojawiają się nowe kierunki (jak choćby konektywizm), które pomijają milczeniem moralny charakter wychowania w epoce cyfrowej.Jeśli jednak zapomnimy o kształtowaniu cnót, to nic nie uchroni dzieci i młodzieży przed „oszołomieniem” i „porwaniem” przez internetowy, nie zawsze wspaniały, świat. Sztuką jest takie wychowanie, które potrafi uchwycić granicę między dobrem a złem i pozostawić dziecko czy młodego człowieka po tej dobrej, właściwej stronie.

\footnotetext{
${ }^{27} \mathrm{~W}$ tradycyjnym kanonie etycznym wyrażała to cnota eutrapelii, której zadaniem było uformowanie człowieka w obszarze zabawy tak, by unikał on wszelkiej przesady, zarówno w aspekcie jej nadmiaru, jak i niedomiaru.
} 


\section{Summary}

\section{"New" pedagogical problems in the epoch of „new media”}

The aim of the classical pedagogy used to be the moulding in a person the virtues and moral values useful in the honest life. Postmodernism led to many cultural changes as well as the whole concept of education. Postmodernist education gave priority to the promotion of freedom, the rejection of absolute and moral values. It should be up to a person to decide what is true and what is false, what is good and what is evil. This concept of education is quite dangerous for the development of "new media". Nowadays, the main educator for a large number of children and teenagers became the Internet. Besides all the advantages, there are various traps which await them online. For more than half a milliard people in the world, out of that more than 8 million in Poland, the modern "god" is Facebook, founded by Mark Zuckerberg in 2004. Lot of children and young people spend hours in virtual network. They are everyday household members of Facebook, Twitter, MySpace, YouTube, Communicators and blogs as well as the slaves of computer games. The computer network addicts and leaves sometimes dramatic marks in their lives. For many of them the Internet became an addiction which already requires treatment and therapy. Lot of them live in a permanent daze what results in social isolation, loneliness, growing aggression and falling into pornography and satanism. The children and young people become unaware victims of the virtual-reality matrix. It is more and more difficult for them to find themselves in the real world. They need help and support. They need therefore, wise educators and appropriate upbringing which will help them to distinguish good from evil and choose the GOOD. 
